\title{
How the Mass Media Use Numbers to Tell a Story: The Case of the Crack Scare of 1986
}

Jerome L. Himmelstein

Amherst College, jlhimmelstei@amherst.edu

Follow this and additional works at: https://digitalcommons.usf.edu/numeracy

Part of the Mass Communication Commons, and the Sociology Commons

\section{Recommended Citation}

Himmelstein, Jerome L.. "How the Mass Media Use Numbers to Tell a Story: The Case of the Crack Scare of 1986." Numeracy 7, Iss. 1 (2014): Article 2. DOI: http://dx.doi.org/10.5038/1936-4660.7.1.2 


\title{
How the Mass Media Use Numbers to Tell a Story: The Case of the Crack Scare of 1986
}

\begin{abstract}
Scholars, notably Joel Best and Milo Schield, have emphasized the importance of incorporating social construction into the study of quantitative literacy. Studying social construction involves examining how numbers are produced, how they travel into the mass media, and how the media use them to depict a social problem or discuss an issue. This article presents a case study in the last of these. It asks in particular how important numbers really are in media constructions of a social problem. It focuses on the "Crack Scare" of 1986 in the United States and a classic study in social construction, Orcutt and Turner's "Shocking Numbers and Graphic Accounts." Drawing upon a sample of articles from the New York Times and Newsweek, it argues that the way the media told stories about the Crack Scare actually sidelined numbers, rather than emphasizing them. Numbers are not always as important as some claim them to be.
\end{abstract}

\section{Keywords}

social construction, numbers, mass media

\section{Creative Commons License}

(c) (1) (9)

This work is licensed under a Creative Commons Attribution-Noncommercial 4.0 License

\section{Cover Page Footnote}

Jerome Himmelstein is Professor of Sociology at Amherst College, where he teaches courses on the role of numbers in society, drugs and society, and sociological theory and research methodologies. He has written books on marijuana ("The Strange Career of Marijuana"), the American Right ("To the Right") and corporate philanthropy ("Looking Good and Doing Good: Corporate Philanthropy and Corporate Power"). $\mathrm{He}$ is currently studying how public discourse on marijuana has changed over the last few decades. 


\section{Introduction}

"Social Construction" is nothing new to readers of Numeracy. In the inaugural issue of the journal, Joel Best argued that "numeracy needs to address social construction" (Best 2008a). By this he meant that thinking critically about numbers requires that we understand them not as hard nuggets of fact that we discover likes rocks on the ground but as things we create rather like polished gems:

...numbers are socially constructed. Statistics are not nuggets of objective fact that we discover, rather they are people's creations. Every statistic reflects people's decisions to count, their choices of what to count, and how to go about counting it. (Best 2001b, 15)

Milo Schield has emphatically ratified Best's concerns and argued that statistical educators need to do more to help students understand the implications of social construction (Schield 2011).

Studying social construction involves examining how researchers produce numbers and select them for the media, how the media report those numbers, and how the media use them to depict a social problem or discuss an issue. This article focuses on the last of these. It studies the "Crack Scare" of 1986 in the United States, starting with a classic study in social construction, "Shocking Numbers and Graphic Accounts" (Orcutt and Turner 1993), which examines how the print media distorted survey data on drug use by high school seniors. Gal (2002) has called the study a "potent example" (p. 15) of how the media can manipulate numbers and a model of the critical skills essential to statistical literacy. Taking up where Orcutt and Turner (1993) leave off, my article asks in particular how important numbers really were used in media constructions of the Crack Scare. It argues that sometimes the media construct social problems in ways that sideline the role of numbers.

This article makes two overall points for those interested in the contribution of social construction to statistical literacy. First, statistical literacy requires coming to terms with the absence as well as the presence of numbers in the mass media and with how the media combine numbers with other discursive resources to depict a social problem or discuss an issue. I develop this point systematically throughout this article by looking at the media's use of numbers during the Crack Scare. Second, statistical literacy needs to focus on the full range of human decisions that go into the social construction of numbers. Before the media report a number, someone - researchers or sponsoring agencies - has to make that number available. Once the media have reported a number, they then have to decide how to use it in constructing a social problem or framing an issue. I develop this point toward the end in my conclusion by connecting the current article to my previous work (Himmelstein 2013). From this perspective, studies 
like Orcutt and Turner (1993) look at only one point on a continuum of decisions that go into the social construction of numbers.

I should also clarify here that I envision the case study presented here as useful for informing the thinking of educators rather than one that might be directly used in the classroom, though I would not preclude the latter.

\title{
Theoretical Framework
}

Scholars who study the role of numbers in public discourse tend to agree on one simple claim: "Numbers Rule the World" (Gigerenzer et al. 1989, 238). That is, numbers have come to dominate public discourse. They have a unique power to define and shape social reality. Speaking for the literature on quantitative literacy, Steen asserts that "quantitative methods" have become "the dominant form of acceptable evidence in most areas of public life" (Steen 2001, p. 3). Summarizing historical research on quantification, Gigerenzer et al., argue that "from Earned Run Average to the probability of today's precipitation to the certification of a new drug for sale, statistics and probability are all pervasive." (Gigerenzer et al.1989, 238) Studies of the "politics of numbers" argue that "numbers are the rhetoric of our times" (Keyfitz 1987, 247) and that measurement has moved "toward the center of political life" (Prewitt 1987, 261). In his classic work on the social construction of suicide rates, Douglas argues that

\begin{abstract}
Throughout the Western world today there exists a general belief that one knows something only when it has been counted. Enumeration has become the cornerstone of knowledge. Though this epistemological assumption was first applied in the natural sciences, it has come to dominate Western man's thought concerning human affairs as well....[T]his assumption has today become one of the most important assumptions of common-sense epistemology. (Douglas 1967, 163)
\end{abstract}

Numbers not only increasingly describe the world, but also shape it, it is further argued. We increasingly use numbers to evaluate and "discipline" institutions and the people in them. We live increasingly in an "audit society" or "audit culture," scholars argue (Strathern 2000; Power 2007; Sauder and Espeland 2009). How we quantify reality can also shape social identities (Urla, 1993; Igo 2007).

One reason that numbers are so prominent and powerful, it is argued, is that they travel well. They are "abstract, concise, and portable" and decontextualize easily (Sauder and Espeland 2009, 72). Once removed from the usually complicated process through which human beings produce them, they take on a "seeming objectivity" (Thernstrom 1987, 303). We easily fetishize them, argues Best, turning them into nuggets of hard fact divorced from the human decisions that went into creating them: 
In our society, statistics are a sort of fetish. We tend to regard statistics are though they are magical, as though they are more than mere numbers. We treat them as powerful representations of the truth; we act as though they distill the complexity and confusion of reality into simple facts. (Best 2001, 160)

The common sense of the sociologies of quantification, then, is that numbers are very important, indeed of singular or primary importance in public discourse.

The sociological studies of social problem construction and of media discourse point to a different common-sense understanding of numbers. Sociologists have long argued that claims-making about social problems uses not only numbers, but "typifying examples," compelling narratives, and the testimony of both experts and victims (e.g., Best 1990 2008b). They have also argued that public discourse on political issues consists of a "diverse array of symbols, images, and arguments" (Ferree et al. 2002, 14) or "metaphors, catch phrases, visual images, moral appeals and other symbolic devices" (Gamson 1992, 24), though of course organized into coherent frames.

Juxtaposing these literatures in this way allows us to pose a set of questions about the use of numbers in public discourse. My point is not that Best or Steen or Schield have gotten things wildly wrong. Numbers are important in media discourse and the statistically literate person must know how to evaluate their use. However, the statistically literate person also must sometimes come to terms with the absence of numbers and with the rhetorical devices that substitute for numbers.

Our questions include the following: How important are numbers in making claims about issues in media discourse? Do the media systematically prefer big numbers over small ones, as some contend (Best 2001, 2004; Orcutt and Turner 1993)? How much attention do the media give numbers relative to other discursive resources, such as typifying examples, compelling narratives and the testimony of experts? How do the media combine numbers with these other discursive resources to make claims or frame issues? What kinds of stories do the media tell and how do they incorporate numbers into these stories? To elaborate:

(1) Best $(2008 \mathrm{c}, 11)$ points out that most social problems exhibit a pattern of "lots of less serious cases and relatively few serious ones." This allows the media "to couple a terrible example to a statistic about the problem's scope." Our question has to do with the relative weight the media give each part of this coupling: Do they emphasize the examples, the statistics, or both? Even where the numbers are important, they may get little attention. The media may use numbers to frame the picture they paint, but then focus attention on the more compelling, colorful parts of the picture, not the frame. Or to switch metaphors, the media may use big numbers as the stage scenery in front of which the drama of terrible examples got carried out. 
(2) Andreas and Greenhill $(2010,266)$ note that although we live in a world preoccupied with quantification, "numbers do not float freely. Numbers alone are too abstract. They resonate most powerfully if there is an accompanying story or image." These authors add that "numbers need narratives" as much as "narratives need numbers." Our questions are these: What stories do the media tell and how do they tell them? Are all stories equally conducive to incorporating numbers? What kinds of stories give numbers a big role and which do not?

(3) The role numbers play in media discourse may depend on to whom the media give "standing," whom they treat "as an actor with a voice, not merely an object being discussed by others" (Ferree et al. 2002, 13). In our case, we are interested specifically in whom the media designate as having relevant knowledge about an issue or problem. As Ericson $(1998,2)$ argues, the media "establish factuality by using credible sources who make statements that can be quoted as fact without further investigation." Gigerenzer et al. (1989) argue that the growing importance of numbers goes hand-in-hand with the rise of a distinct kind of expert, "one whose claims rest more on information and formal technique than on concrete experience and personal judgment" (p. 235). In the context of the Crack Scare, this suggests two kinds of experts or credible sources. The first kind of expert, whom we shall call "scientists" or "researchers," speaks from a putative knowledge of research and the numbers this research produces, such as survey research on drug use. The second kind of expert, whom we shall call "social problems workers" (Best 2008b), speaks from a putative firsthand knowledge gained from dealing with the drug problem and thus claims an expertise with relatively little connection to numbers. This category includes primarily law enforcement personnel and treatment specialists. Our question here is what mix of experts the media cite.

\section{The Crack Scare as a Historical Case Study}

In the midst of the escalating War on Drugs in the 1980s, the media announced, beginning in late 1985, that a cocaine epidemic had struck the United States, especially involving a new smoked form of cocaine known as "crack." Attention in both the print media and television rose in the spring of that year, peaked during the summer with the deaths of two star athletes, Len Bias and Don Rogers, continued into the early fall, and then declined toward the end of the year.

The Crack Scare of 1986 has been well studied. Scholars have analyzed trends in media attention and inter-media influences (Shoemaker 1989; Hartman and Golub 1999). They have looked at the changing ways the media framed cocaine use and the broader cultural meaning of the Crack Scare (Reeves and Campbell 1994; Wagner, 1997). They have examined its causes, consequences, and the context within which it occurred (Trebach 1987; Baum 1996; Bertram 
1996; Reinarman and Levine 1997; Massing1998; Musto 1999). They have debated how "real" the crack epidemic was (Goode 1989; Johnston 1989; Jensen et al. 1991; Orcutt and Turner 1993; Reinarman and Levine 1997).

The Crack Scare makes a good case study for historical analysis for several reasons. First, because it has been so well studied, we have a solid backdrop of information on the basis of which to focus on the use of numbers specifically. Second, it has attracted a classic study in the social construction of numbers (Orcutt and Turner 1993), but one that has looked at only part of the process, as we shall see. Third, the central claim in the Crack Scare - that cocaine use was spreading not just in poor urban neighborhoods but across a broad swath of middle-class America - was inherently a quantitative claim apparently crying out for numerical support. Fourth, this case has built into it kinds of variation that will prove important to our study. The Crack Scare bubble expanded and burst very quickly. The media frenzy quickly gave way to at least a few second thoughts. Uncontested claims gave way to contestation. The Crack Scare thus allows us to compare the use of numbers in those two very different situations close to each other chronologically. In addition, we can compare moments within 1986 at which numbers on drug use were just released and hence news in their own right to moments at which they had been out and available for quite a while.

These strengths, I would argue, offset the obvious problems with focusing on the Crack Scare. First, one case "proves" nothing; it can at best suggest ideas that one can then apply in other contexts. Second, the Crack Scare occurred nearly thirty years ago. Ideally one would like a more recent case. In the conclusion to this article, I suggest ways in which future research might address these shortcomings.

\section{"Shocking Numbers and Graphic Accounts"}

"Shocking Numbers and Graphic Accounts: Quantified Images of Drug Problems in the Print Media" (Orcutt and Turner 1993) showed how at the height of the 1986 Crack Scare, Newsweek magazine transformed data from a national survey of high school seniors, which showed that cocaine use had leveled off in the early 1980 s, into a graph that showed a steep increase in use.

The graph appeared in "Kids and Cocaine," the cover story of Newsweek's March 17, 1986, issue. It drew upon data from Monitoring the Future (MTF), an annual survey of drug use among a sample of high school seniors. Orcutt and Turner started with the original trend data from the MTF, which showed that lifetime, past-year and past-month use of cocaine among high school seniors had increased sharply in the late 1970s and then leveled off in the first half of the 1980s. They identified three critical choices the editors of Newsweek made to construct a graph showing an apparent steep increase in cocaine use during the 
early 1980s. First, they chose to present data on lifetime use of cocaine, rather than use in the past year or past month, thus generating the largest numbers possible. Second, they truncated the time line by limiting the graph to the years 1980 to 1985, even though most of the increase in cocaine use occurred before 1980. Third, they rescaled the vertical axis (the percentage of high school seniors who had ever used cocaine) to a range of 15 to 17 per cent. The resulting graph had an impressively steep trend line.

Orcutt and Turner's analysis also shows how these decisions are largely invisible unless one can track down the original data. Readers might have noticed that the vertical axis of the graph was highly truncated. However, they would not have necessarily known that the magazine chose one set of numbers (lifetime use of cocaine) over other sets (use in the past year or past month) or that looking at trends in cocaine use over a longer period would have given very different results.

Orcutt and Turner note a continuing penchant for "shocking numbers" in the media through the summer of 1986, but then a certain modulation. By September, some in the media began to question the extent of the cocaine epidemic. Time and U.S. News \& World Report at that point presented data from the MTF study that did not truncate the time line or choose the largest numbers.

Orcutt and Turner's analysis is a classic study of social construction. However, it tells only part of the story. My analysis begins where theirs ends. Focusing primarily on the graph and the associated text takes the numbers out of context and makes it difficult to assess their significance within the overall media story. What do we see when we put the graph back in context, when we look not at how the media constructed numbers, but at how the media used them? My goal is not to criticize Orcutt and Turner (1993), but to complement them.

\section{Methods}

My analysis focuses on Newsweek and the New York Times. Newsweek's "Kids and Cocaine" article was one of the first to discuss cocaine use as a nationwide problem. The magazine's editors emphasized its long-term commitment to covering drug abuse in America: "an epidemic and a national scandal-and a story NEWSWEEK has been covering for 20 years" (Newsweek 1986, 3). I also chose the New York Times, because to the extent that any media outlet led coverage of the cocaine epidemic, the Times did (Reese and Danielian1989). It is unlikely that using other media outlets would have changed our findings. As Reese and Danielian (1989) argue with specific application to the Crack Scare, "Major media cover issues in a similar fashion and at roughly the same time. These similarities seem more profound during periods of intense media attention" (p. 42). 
In both cases, I looked primarily for longer articles, because focusing on relatively large chunks of text allows us to place numbers in the broader context of media discourse, to see how the numbers get used with other discursive resources. For both publications, I did a Lexis-Nexis search for "cocaine" covering the period from November, 1985, through December, 1986.

For the New York Times, I looked for articles that were either on the front page or at least 1000 words long. From these, I selected thirteen articles that focused primarily on some aspect of the cocaine problem, rather than policy or law enforcement. Six were front-page articles, and another four were on the front pages of inside sections of the newspaper. My sample included all the articles from the Times that previous studies had discussed.

The Newsweek search yielded 103 articles. Winnowing out the many articles in which cocaine was tangential left 29 articles. Most of these appeared in just four issues that devoted a cover story to cocaine: March 17, June 16 and 30, and July 28. I further removed articles that focused on drug control rather than drug use and shorter articles, for example, "Top of the News" pieces that introduced the cover story. This left five articles, including the anchor pieces for each cover story. As with the Times, the sample included all the stories discussed in previous studies.

\section{Data Analysis}

\section{Newsweek:"Kids and Cocaine"}

The Newsweek cover story on "Kids and Cocaine" begins with an alleged case of an ice cream company selling cocaine to kids from its trucks (Morganthau 1986a). It then says,

It would be funny if it weren't so frightening-and if in cities and suburbs all across the nation, a generation of American children were not increasingly at risk to the nightmare of cocaine addiction. As thousands of teens have already learned to their families' infinite sorrow, coke is it in the 1980s-the most glamorous, seductive, destructive, dangerous drug on the supersaturated national black market.

To support this claim of a looming menace, the article initially offers not numbers, but the testimony of a former high school guidance counselor currently running a drug-treatment center: "There are two trends in cocaine use: Younger and younger, and more and more."

We are ill-equipped to deal with this looming epidemic, the article continues, because too many Americans see cocaine as an expensive mildly addictive recreational drug usually snorted by "movie moguls, rock stars, and professional athletes." The reality, however, is different: Cocaine is now available as "crack," a new, inexpensive, smoke-able version. As a result, "cocaine abuse is the fastestgrowing problem in America for adults and school-age children alike." 
The article then turns to a narrower problem, crack and the violent urban crack markets, without quite leaving the broader one.

Crack is not widely used in many areas of the country - but that may only be a matter of time. It is already creating social havoc in the ghettos of Los Angeles, New York, and other large cities, and it is rapidly spreading into suburbs on both coasts.

Connecting the two problems, the article asserts that the spread of crack "is probably a major reason that cocaine abuse among the young is on the rise." It briefly cites an epidemiologist at the National Institute on Drug Abuse to support this speculation, without however citing any numbers regarding overall cocaine use.

The article then weaves together two narratives. The first tells of crack use in urban ghettos in Los Angeles, Houston, New York, and Atlanta: the strung-out users, the fortified crack houses, the horrific violence, and the overwhelmed forces of law and order. The second tells of cocaine use and dealing in the world well outside the urban core: Orange County, the San Fernando Valley, and Corpus Christi.

The first story is told with the help largely of the police. A New York City police officer tells of a crack-house bust. A Los Angeles detective confesses, "We have lost the cocaine battle." Houston police testify to the immense size of the cocaine market and the huge profits. The second story is viewed through the eyes of police but also former users and dealers. A Los Angeles police detective tells us that crack is everywhere: "It makes no difference whether it was a white, affluent high school, a black inner-city school, or a Latino school." Users testify to how all-encompassing and morally debasing crack addiction is. One says, "I wanted to do more right away. I would lie, steal—anything for a hit off the pipe. It gets hold of you real fast." A dealer talks about the ease with which he could get and sell cocaine: "one phone call" could "get you a quarter of a pound of coke. I sold to kids my own age, and subcontracted to my brother-in-law to sell to attorneys and judges."

"Kids and Cocaine" connects the two narratives at several points. "In many ways," it says, "crack houses are the modern equivalent of opium dens-and their clientele includes young people from the suburbs as well as the city and from virtually every level of society." In Atlanta, "suburban teens have begun driving into the city to make quick curbside purchases." A prosecutor in Camden, New Jersey, professes that "the city's contagion has already spread to the suburbs." In short, what happens in the ghetto is not staying there.

About two-thirds of the way through, the article cites the numbers tied to the graph analyzed by Orcutt and Turner (1993):

Cocaine abuse by school-age children is growing rapidly, and experts somberly predict that the worst is yet to come. An annual survey conducted by the Institute of Social Research at the University of Michigan shows that the percentage of high school seniors 
who have ever tried cocaine has nearly doubled in the past 10 years, from 9 percent to 17.3 percent (chart).

The text accompanying the chart emphasizes the big numbers: "Within the next two years, more than 20 percent of high school seniors may have tried cocaine."

The article then devotes three paragraphs (of a total of 14) to the comments of Lloyd Johnston, principal investigator on the MTF study. Without citing additional numbers, Johnston points out that compared to other industrialized countries, the U.S. has a larger percentage of young people using illicit drugs. $\mathrm{He}$ also notes that the percentage of high school students who say cocaine is available to them is increasing and that very few high school seniors see experimenting with cocaine as a great risk.

The graph and associated numbers from the Monitoring the Future study are certainly important. They provide the numbers to anchor the details of the article in the big picture of a cocaine epidemic. They also provide the opportunity for Johnston to advance Newsweek's narrative by discussing other features of the big picture.

Overall, however, "Kids and Cocaine" is about terrible examples and compelling narratives. It dissolves the big story (nationwide crack epidemic) into a series of compelling small stories, and these stories are anchored in urban ghettos: The inner city becomes not only the source of the drug but a template for what the problem will soon enough look like elsewhere.

The article tells its stories with the help primarily of social problems workers as well as drug users and dealers, not researchers like Johnston. Of the 21 persons cited, only four were identified by their professional degrees or their affiliation with a research organization or major study. Of the rest, 13 were police and treatment specialists, and four were users and dealers. Firsthand, everyday knowledge and those believed to have it trump scientific expertise in portraying the scope of the cocaine problem.

\section{Other Newsweek Articles}

Numbers, especially big numbers, play a larger role in "Kids and Cocaine" than in any other Newsweek story. It is also the only story that uses a researcher to advance the narrative in a substantial way. Subsequent Newsweek cover stories on June 16, June 30, and July 28 tell the story of the cocaine epidemic by focusing squarely on terrible examples: "cocaine babies" (Barol 1986), addicts struggling with treatment (Seligmann 1986), open-air drug markets (McKillop 1986), and crack in the inner cities (Morganthau 1986b). They simultaneously transform the big, general, national story, a cocaine epidemic across America, into a series of small, specific, local ones.

"Crack and Crime" (Morganthau 1986b), which anchors the June 16 issue, announces, again, that "crack-smoke-able cocaine-has suddenly become 
America's fastest-growing drug epidemic." While this claim talks about "America" generally, the story focuses nearly all its attention on the inner cities, Boston, Los Angeles, Miami, Detroit, Houston, and New York. In each, our guides are police officers and detectives, who testify to the enormity of the problem and the uphill enforcement battle.

Even when "Crack and Crime" moves out from the ghettos to the rest of society, it relies primarily on police and treatment personnel to make its broader points. It announces that "Crack has captured the ghetto and is inching its way into the suburbs; its users come from all social strata and all walks of life." In support of this claim, it turns to Arnold Washton, "a respected drug abuse specialist who operates a national cocaine hot line," who says that "crack and rock are now widely available in 17 major cities and 25 states from coast to coast." At another point, the article says, "there are ominous signs that crack and rock dealers are expanding well beyond the inner city." It cites a policeman from Los Angeles who says crack houses are opening in the San Fernando Valley and reports from Florida law enforcement personnel that the "crack epidemic" has hit "every city, county, and almost every little town" in the state.

The article does briefly cite a 1982 survey by the National Institute on Drug Abuse reporting that 4.2 million Americans reported having used cocaine within the previous month, but this big number is not linked to a researcher who might provide extended commentary on the cocaine problem. Instead, the article returns quickly to Washton:

The growth in the past nine months is alarming," says Arnold Washton. "In September '85 we had not gotten a single call [on the cocaine hotline] about crack. Now, 33 percent of all coke users who call are talking about crack addiction. The explosion has taken place in the past six to nine months. It's a true epidemic.

Overall, numbers, especially about broad patterns of drug use, play at best a supporting role.

"An Inferno of Craving, Despair, and Dealing," also in the June 16 issue, presents the "entrenched sociopathy of the Crack Plague" in "the hub of the crack district in New York's Times Square" (McKillup 1986). It weaves its story around the lives of two dealers (Eare and Linda) and one user (Hector). It presents no numbers on the number of cocaine addicts and the scope of the market, and the story does not seem to need them at all.

"Crack: The Road Back," which anchors the June 30 issue, tells the cocaine epidemic story in terms of overwhelmed treatment programs: "So many people have been overwhelmed by crack - and the epidemic has happened so quicklythat drug-rehabilitation centers are straining to meet the heavy demand for treatment" (Seligmann 1986). In support of this claim, the article cites drug treatment specialists, one of whom says, "There seems to be an unlimited demand. If our facility could accommodate five times the number it does, it still 
wouldn't be enough." It also cites patients struggling with their addiction. In passing, it mentions only a few numbers: the 43,000 treatment slots in New York State and the "2,200 calls a day in recent weeks (up from a previous peak of $1,200)$ )" to the national cocaine hot line.

Finally, "Cocaine Babies: Hooked at Birth," the central article to the July 28 cover story, starts with horrible stories of two babies newly born to cocaineaddicted mothers (Barol 1986). Guillermo "goes into spasms when he is touched. His eyes don't focus. He can't stick out his tongue, or suck." Paul "needs a respirator to breathe and a daily spinal tap to relieve buildup on his brain." It ends with Electra, a cocaine addict, and her seven-year-old daughter, both struggling against the legacies of addiction. In between, the story is told and pushed along by doctors at hospitals across the country, especially those in neonatal units.

Numbers appear briefly and tentatively. The number of newborns with cocaine in their urine has increased from ten a year in a Los Angeles hospital in 1984 to more than 180 in the first half of 1986. The number of drug-addicted mothers at a New York City hospital has jumped from 70 to 150 in the past year. The article is quick to discount the numbers, however, falling back on the testimony of physicians: It is "difficult to pin down exactly how many" cocaineaffected babies there are, but "doctors are certain that the number...is rising." The testimony of neonatologists and other physicians from Boston to Los Angeles carry the story forward.

Overall, Newsweek paints the national cocaine epidemic as a series of local stories told by social problems workers and drug users and dealers. The five major stories presented here give standing to 58 individuals. Of these, 64\% are social problems workers, police, treatment specialists, and physicians. Another $19 \%$ are drug users and dealers. Only a handful are researchers. The articles give numbers brief attention, perhaps enough to suggest a broader picture, and then move on.

\section{The New York Times}

We see similar patterns in the New York Times. In a series of articles, the Times made its own announcements of the cocaine epidemic. The headlines capture the messages well: "Extra-Potent Cocaine: Use Rising Sharply Among Teen-Agers" (March 20), "Hearing Called to Explore Use of 'Crack' by Teenagers" (April 27), "Crack Addiction Spreads Among the Middle Class" (June 8), "Use of the Drug 'Crack' Growing on Long Island" (June 8), "Police Say Use of Crack is Moving to Small Towns and Rural Areas" (September 10).

The March $20^{\text {th }}$ article begins, "In dramatically rising numbers in the last five months, teen-agers in New York City and its suburbs have been using 'crack,' an especially potent and addicting form of cocaine, according to state and local drug officials, educators and experts on drug abuse" (Kerr 1986a). The problem afflicts 
"the wealthiest suburbs of Westchester" as well as "the Bedford-Stuyvesant section of Brooklyn." This seems to be a claim about general patterns of use; however, the article tells its story largely in terms of terrible examples, the dramatic rise in teens seeking treatment or calling hot lines, that is the subset of teens with apparently bad drug problems. Despite the broad headline, the story the article tells is a local one, about the New York metropolitan area and more pointedly about specific communities in that area.

The central testimony in the article comes from those who can talk about the influx into treatment programs in the New York Area. Some are social problems workers connected to treatment programs and drug hotlines. For example:

Wayne Rothwell, director of a drug treatment program for young people at South Oaks Hospital in Amityville, said he had seen evidence of widespread use throughout Suffolk County. Addicted youths, he said, were coming from many affluent North Shore Towns.

Others are presented as researchers connected to public health or law enforcement organizations:

"It's all over the place," said John French, the chief of research and evaluation for the New Jersey Health Department's alcohol, narcotics, and drug abuse unit. "There are simply not enough treatment programs to handle the demand."

"It's growing much more rapidly than we had thought," said William Hopkins, the director of the street-research unit of the State Division of Substance Abuse Services.

Whatever the status of the speaker, the key point is that their claims, though vaguely quantitative ("all over the place," "growing much more rapidly"), do not require any systematic evidence or numbers. Instead what they say is validated by their firsthand experience, their self-evident expertise, or both.

Numbers appear only once, and they are small ones: "Between 65 and 70 crack users a month are now being treated at the Nassau County Medical Center." Indeed, the article acknowledges that "few statistics are available on the use of crack," but obviously does not see this as requiring it to modulate or qualify the broad claims of the headline.

A month later, the Times reported on impending hearings before the suburban Westchester County Board of Legislators "to draw attention to the growing use of the especially addicting form of cocaine and to its popularity among Westchester teen-agers" (Melvin 1986). Again, this is a local story. After quoting the three members of the board calling the hearings, the article largely tells a story of treatment and prevention programs overwhelmed by crack addicts seeking treatment. It relies primarily on representatives of these programs, along with a smattering of police, to tell the story. Arnold Washton, identified here as both a head of a local addiction-treatment center and research director of the National Cocaine Hotline, describes the dangers of crack and then testifies to the magnitude of the problem in terms of the number of people seeking treatment: 
"The problem is as bad in Westchester County as anywhere in the country. We are getting as many inquiries here as treatment facilities in major urban centers." In a comment echoed by others, Washton blames the problem on Westchester County's proximity to New York City. Other treatment and prevention specialists describe how their programs are inundated by crack users. The director of one counseling center, for example, says that his "center was already operating at 100 percent of capacity and programs such as his would have to find alternatives, such as adding group-therapy programs, to handle the flood of crack abusers."

Numbers are few and relatively small. Washton says that his facility admits "three to five teenagers a week with crack addiction." A County Legislator notes that police in one community made 700 cocaine-related arrests in the previous year. Finally, the article presents the results of a survey of prevention specialists:

In an informal survey conducted last week by Student Assistant Services among its counselors in 24 county high schools, the use of crack was estimated to be as low as 1 percent to as high as 35 percent in the high school population, for an average of 10.9 percent.

These numbers, of course, do not report drug use but summarize the opinions of more social problems workers.

On June 8, the Times ran another article on "Crack Addiction Spreads among the Middle Class" (Kerr 1986c), which reported:

According to drug treatment specialists, users, and some dealers of the drug, many of the college-educated and professional people who smoke crack have used cocaine and marijuana on occasion for years. And for years they have dismissed warnings about those drugs as exaggerated.

But as crack use has spread through the city and suburbs in the last six months, they said, a growing number of upper-middle-class, casual drug users are surprised to find themselves suffering a severe crack addiction.

This article tells its story in several ways. First, it cites users and dealers. For example, one user testifies that "at my company people are getting toasted all over place." A drug dealer reports distributing crack throughout affluent neighborhoods in Westchester County. Second, it cites the ethnographic findings of the street-research unit of the State Division of Substance Abuse Services on drug dealing in the Wall Street area. Third, it cites a survey of 500 callers to the National Cocaine Hotline, many of whom were affluent adults, as well as quoting Washton, "We are seeing business executives who have switched from cocaine powder to crack, and it hasn't turned out well for them." Finally, the article refers to unspecified "evidence gathered by Government agencies that monitor drug abuse."

Another article in the same issue of the Times, focusing on Long Island, states that "Experts agree that the Island is in the first stages of a drug epidemic; based on past experience the worst is yet to come" (Domash 1986). The experts 
include the chief of the Suffolk County District Attorney's office, the commanding officer of the Nassau County narcotics bureau, members of the Nassau police special operations bureau, and the Commissioner of the Nassau County Department of Drug and Alcohol Abuse. Typical of their comments is the report from two narcotics officers that "the use of crack has reached epidemic proportions - as bad as the heroin problem in the 1960s." All of these social problems workers draw upon their own experience or the experience of their agency's personnel and thus do not have to supply numbers. In addition, as the article acknowledges, there are no numbers there: "Crack is so new a phenomenon that the police have no accurate statistics on how many users there are and how much money its sale represents." The lack of accurate statistics, however, does not deter the Times from insisting that in fact an epidemic is unfolding.

A September 10 article bases its headline claim that "Crack is Moving to Small Towns and Rural Areas" on "interviews with officials of dozens of local and county police agencies as well drug treatment centers" (Schmidt 1986). Only rarely does the article find numbers to validate these claims. Florida's state crime laboratories provide numbers showing that the percentage of narcotics cases involving crack cocaine in particular was rising. A drug treatment center in Gadsden, Alabama, reported that $85 \%$ of the people on its waiting list are "believed to be addicted to crack." Otherwise the claims of police, treatment personnel, and other social problems workers are validated by firsthand experience.

Other major articles on the cocaine epidemic in the Times focus less on the cocaine epidemic itself than on some of its consequences. For example, two articles, on February 3 and August 25, report on babies born to cocaine-addicted mothers (Gross 1986, Kerr 1986d). Another, on May 16, frames the problem as cocaine abusers overwhelming treatment services (Kerr 1986b). Still another, on November 24, reports that the rising number of cocaine-related arrests is overwhelming the criminal justice system (Kerr 1986f). Here too, social problems workers of various kinds tell the story. Here too, numbers are rare. The remainder of the articles in the sample is similar to these.

Overall, numbers are relatively rare in the Times articles. Large numbers about the overall magnitude of the cocaine epidemic are even rarer. This makes sense in terms of the stories the Times tells and how it tells them. The articles are only ostensibly about a national problem. Instead they report on local problems, whether around New York City or elsewhere in the nation, or they report on pieces of the problem, treatment programs overwhelmed, courts clogged, or hospitals filled with cocaine babies. They focus not on broad populations of users, but on smaller populations showing up in treatment programs or the courts. They use the testimony of people with firsthand experience, not experts with studies 
and numbers, to tell the story, primarily a range of social problems workers and occasionally users and dealers. The thirteen major stories in the Times cite 85 individuals, of whom 55 or $65 \%$ are social problems workers. Only $12(14 \%)$ are researchers of one kind or another, while the rest are politicians, users and dealers, and others.

Two of the Times articles, however, did cite numbers frequently, and these exceptions are illuminating.

First, in early July, the Monitoring the Future Study released additional data from its 1985 study, focusing on the follow-up studies of former high school seniors who were now in college and/or young adults. The National Institute on Drug Abuse also released data from a study of medical examiners and emergency rooms across the country. The newness of the numbers made them newsworthy. The headline to a July 11 Times article announced that "U.S. Says Cocaine-related deaths are rising" (Brinkley 1986). It reported first on numbers "made public at a news conference today." Dr. Donald I. MacDonald, administrator of the Alcohol, Drug Abuse and Mental Health Administration said that reports from medical examiners in 25 metropolitan areas showed that cocaine-related deaths had risen from 185 in 1981 to close to 600 in 1985, while reports from 700 hospitals showed that the number of cocaine-related cases showing up in emergency rooms rose from 3,300 in the 1981 to about 10,000 in 1985. The article then cited other numbers that both corroborated and questioned these numbers. On one hand, the Drug Enforcement Administration reported that the amount of cocaine used in the country had been steadily rising. On the other hand, the National Institute for Drug Abuse reported that the number of regular cocaine users had remained stable.

Patterns of reporting data from the Monitoring the Future Study in particular bear out the idea that the media tend to report numbers when they are newly released and hence newsworthy. The Institute for Social Research released two press releases on the $1985 \mathrm{MTF}$ study, one on November 6, 1985, and the other on July 7, 1986. A Lexis-Nexis search among "U.S. News and Wires" and "Magazine Stories Combined" using the terms "Lloyd Johnston" or "Institute for Social Research" or "Monitoring the Future" returned 72 articles (after duplications were removed) for the November, 1985, to December, 1986, period, 31 of which were drug-related. Of these 31 articles, 17 or $55 \%$ appeared within two weeks of either press release. Several others discussed the MTF data in conjunction with other data that had been recently released.

Overall, how the media report numbers when they are new is not a good guide to how the media use numbers when reporting other stories. There is a slippage between paying considerable attention to numbers about drug use as news and not using them when constructing social problems. 
A second Times article, on September 1, which paid considerable attention to numbers, reported not on the cocaine epidemic but on debate over whether there really was a cocaine epidemic (Kerr 1986e). "Use of Crack: The Future; Unclear How Widely the Drug Will Spread" reported that "drug abuse experts are still struggling to define the full dimensions of the crack problem and whom it affects" and that it is "still unclear just how much crack use will grow in other cities, and whether, like heroin, it will remain primarily an affliction of poorer neighborhoods." The article noted that "experts in drug abuse" claimed that many statements by public officials had been "based on vague or poorly defined information." It acknowledged that the issue was politically charged:

The number of cocaine users in the nation-and whether that number has grown at allis a highly charged political subject these days, with some Democrats saying the number of users has risen dramatically and the Reagan Administration maintaining the number has leveled off.

Finally, the article closed by referring to "several social scientists" who "chastised politicians and the media for making statements based on poor scientific data." Numbers abound in this article, on crime rates, cocaine-related emergency room cases, callers to the National Cocaine Hotline, and cocaine use by high school seniors.

In short, it seems that numbers also figured more prominently at those rare moments when claims about cocaine use were contested or acknowledged as problematic. As Gigerenzer et al. $(1989,239)$ argue, "Where values clash and consensus is elusive, numbers and the techniques that manipulate them are esteemed for their ostensible neutrality."

\section{Discussion}

The key purpose of this paper has been to pose questions. Rather than assuming that numbers dominate public discourse, it has sought to problematize this claim. It has done this by bringing together a key insight from the sociology of quantification, the growing importance of numbers in public discourse, with a key insight from both the study of social problems construction and the study of media discourse, making claims and framing issues draw upon multiple discursive resources. The questions have included: How important are numbers in making claims about issues in media discourse? Do the media systematically prefer big numbers over small ones, as Orcutt and Turner (1993) and others suggest? How much attention do the media give numbers relative to other discursive resources, such as typifying examples, compelling narratives and the testimony of experts? How do the media combine numbers with these other discursive resources to make claims or frame issues? 
I have tried to answer these questions tentatively by exploring a case study, the Crack Scare of 1986. I started where Orcutt and Turner's classic study left off. Orcutt and Turner (1993) looked at how Newsweek constructed a specific graph and how other media outlets presented data from the Monitoring the Future study. I have looked at how the media used the graph and other representations of numbers in constructing the broader claim that an epidemic of crack use had beset America.

My basic conclusion is that numbers, especially big ones, did not figure prominently in how the media constructed the crack epidemic of 1986. Newsweek and the New York Times simply did not spend a lot of time presenting and discussing numbers about drug use. When they presented numbers, they were rarely big ones. Numbers gained prominence primarily when they were newly released or in those few instances when the conventional wisdom was challenged. As long as consensus ruled and the authorities spoke with one voice, numbers played a distinctly minor role. There was a real slippage between reporting the numbers as news and using numbers to report the news.

Why don't numbers loom larger? Several answers are possible.

Perhaps a little bit of numbers simply goes a long way. Once turned from the products of complex human decisions into solid nuggets of fact, numbers seem to speak for themselves and thus do not need much discussion. Having used them to frame the picture, the media can then focus on the more interesting details within the frame. As we shall argue below, however, this argument is too simple. The media had choices. Paying little attention to numbers was not inevitable.

Or, perhaps the numbers simply were not there. According to this argument, the media might have used numbers more if the relevant numbers were available. Sometimes, however, numbers were there. Data from the Monitoring the Future Study were available throughout 1986 . Even though these numbers did not show a cocaine epidemic in the mid-1980s, Orcutt and Turner's study shows how the media could and did slice and dice them to show what it wanted to show. The media rarely cited these data. To be sure, the media had no numbers to document the upsurge of cocaine use in Westchester County or New York City, but here the lack of numbers is partly a function of how the media chose to tell the story.

Even if true, both these explanations point to a more basic one: The best explanation lies in what stories the media told, how they told them, and whom they used to tell them. What the media regarded as a good drugs story simply sidelined numbers. As revealed through our research, a good drugs story had at least three elements.

1. Going local. Even when national media talked about what was going on nationally, they told their story as a sum total of local ones, about what was happening in inner-city New York or Los Angeles, suburban Westchester County or the San Fernando Valley. Compelling narratives were local ones, and local 
narratives were not congenial to big numbers or often any numbers at all. Numbers may need narratives, as Andreas and Greenhill (2010) argue, but not all narratives seem to need numbers.

2. Thinking small. The media also preferred to dissolve the big picture of a cocaine epidemic affecting millions into a series of smaller pictures involving much smaller numbers of terrible cases of cocaine babies, over-crowded treatment programs, violent, community-destroying open-air drug markets and crack houses, strung-out addicts and enterprising dealers. Again, this kind of story renders big numbers in particular irrelevant. Indeed, given the limited availability of numbers of any kind on these phenomena, it renders all numbers irrelevant. Best (2008c) argues that a good way to dramatize a problem is to combine big numbers with terrible examples. In this case, the terrible examples all but swamp the big numbers.

3. Journalism by anecdote, not evidence. This gets back to the issue of standing. The media want to cite people whose opinions can stand on their own. Roughly speaking, they have a choice between social problems workers, whose opinions are grounded in firsthand experience, and researchers, whose opinions are grounded in research of some kind. Citing the latter is more congenial to citing numbers; however, the media overwhelmingly preferred social problems workers. Good drugs stories are told by people "on the ground" with firsthand experience, cops on the beat, narcotics task forces, treatment specialists, neonatologists, and others. The media prefer to generalize from the anecdotes of social problems workers rather than the data of researchers.

In going local, thinking small, and journalism by anecdote, we have a kind of metonymy at work. The media conflated a part with the whole. They told a small story and let it stand for or make a case for a larger one. This approach simply sidelines numbers.

Choices about how the media told their stories also involved choices about how to use numbers. The media can use numbers in at least two ways. First, it can use them to indicate briefly the broader picture, to provide the backdrop against which local narratives and terrible examples unfold. Second, it can use numbers as one important element in telling those stories. One way to do this is to use the numbers as a springboard to extended commentary by researchers on the overall dimensions of the problem. In the case of the Crack Scare, Newsweek and the New York Times did this only once, in the "Kids and Cocaine" article. Even there, the commentary of Lloyd Johnston and others played a distinctly subordinate role to local stories and the testimony of social problems workers.

Perhaps the media sideline numbers, because, for them, numbers suffer the defects of their virtues. Or to switch metaphors, they are a double-edged sword. On one hand, numbers travel easily. To return to the words of Sauder and Espeland (2009), they are "abstract, concise, and portable." They are easy to 
abstract from the messy processes through which human beings produce them and once reified they take on the appearance of pure, objective, undeniable nuggets of fact, as Best (2001b) argues. On the other hand, once they become abstract nuggets of fact, they become lifeless as well. To return to Andreas and Greenhill (2010), "Numbers alone are too abstract. They resonate most powerfully if there is an accompanying story or image."

The limited utility of numbers to the media was captured inadvertently during the Crack Scare by Richard M. Smith, then editor-in-chief of Newsweek. Introducing the June 16, 1986, issue, Smith, after citing several numbers describing drug use in America, wrote,

The statistics are abstract. Their consequences are frightening. We have become, by some accounts, the most drug-ridden society in the industrial world. The traders have overrun our lines of defense. "It's lonely out there," a narcotics officer told us, combatweary from trying to fight the laws of supply and demand. (Smith 1986, 15)

The broader understanding of the usefulness of numbers for the media that is implicit here is this: Numbers may be necessary, but they should be as unobtrusive as possible. Cite them and then move on to more vivid ways of telling the story, in this case the testimony of a "narcotics officer."

Of course, we can learn only so much from one historical case, especially one from nearly three decades ago. The results inevitably can be only suggestive. One way to pursue further the questions this paper asks with more recent material would be to come up with a contrasting case. In the mid-1980s the media reported a drug epidemic when drug use in America overall was declining or at least stable. In the mid-1990s, drug use among teens was going up, but the media declined to turn this into an "epidemic" (Deseran and Orcutt 2009). Comparing the use of numbers in these two cases would be instructive. Alternatively, one could look at how the media report and use data from similar studies at several different points in time. At least two surveys, Monitoring the Future and the National Household Study of Drug Use and Health, for example, do annual surveys of drug use in the United States. One might look at how the media have reported the results and used them to tell a story or portray a problem, looking for similarities and differences over time.

\section{Conclusions}

Finally, what should teachers and students of statistical literacy take away from this study? As I said in the introduction, there are two sets of points, the first emerging from the analysis in this article, the second becoming visible when this analysis is combined with my previous work.

First, the current study suggests a specific set of "worry questions" (Gal 2002) about the presence or absence of numbers in the media: How central are 
numbers to the case being made? How do the media combine numbers with other rhetorical tools to make a case about something? If the media don't use numbers prominently, why not? How might a story without numbers look different if relevant numbers were included?

The current study should also remind teachers and students that one needs to think critically about all the rhetorical tools the mass media use to construct a problem or portray an issue. Best argued in Damned Lies and Statistics (2001a) that a critical attitude toward numbers involves avoiding cynicism as well as naiveté. While a naïve or awestruck attitude accepts numbers as hard nuggets of fact, a cynical attitude rejects all numbers out of hand as equally bad, as products of someone's (nefarious) manipulations. The current study can hopefully temper this cynicism by encouraging critical thinking about the frequent absence of numbers and about the other rhetorical tools that the media use to construct a problem or portray an issue. Numbers may be subject to manipulation and multiple interpretations, but, properly used, they provide a kind of evidence that trumps or should trump expert testimony, striking examples, and compelling narratives.

Second, this paper combined with my other work (Himmelstein 2013) also points to a broader point: We need to recognize that the social construction of numbers encompasses more than the moment at which the media get hold of and present numbers. There is both a "before" and an "after." This article has looked at the "after," how the media used or didn't use numbers it reported in other articles on drug use, but there is also an equally fascinating story to be told about the "before," how researchers selected the numbers they present to the media.

Surveys like Monitoring the Future produce huge amounts of data. Even condensing it all into univariate tables runs into hundreds of pages. How do researchers or their sponsors select a very small subset of these data to include in the press releases upon which the media rely in their reporting? How can we even begin to make sense of the selection process?

I approached these questions by first identifying a small number of important choices: Did the researchers emphasize less frequently used illegal drugs like cocaine or more frequently used legal drugs like tobacco and alcohol? Did they lump marijuana with much less frequently used illegal drugs like cocaine? Did they present aggregate results for their whole sample or did they also look at demographic differences (by race, gender, region, etc.)? Did they present larger numbers for longer periods of time (e.g., lifetime use) or smaller numbers for shorter periods of time (e.g., past month use)? How did they decide whether the overall results of their survey were "good" news or "bad" news? To what extent did they attempt to explain, rather than just describe, trends in drug use?

I then compared the press releases from Monitoring the Future during the Crack Scare and to those from the late 1970s through 2011. This allowed me to 
distinguish two possible influences on the choices the researchers made. These choices might be the result of routine practices on the part of the researchers and thus recur at several points in time. Or they might reflect the political moment and thus be unique to one point in time. In some instances, the researchers made choices during the Crack Scare that were similar to those at other times. For example, the data available in 1986 showed that drug use among high school seniors had leveled off in 1985 after declining sharply in the early 1980s. The researchers reported this as "bad" news, apparently bending to the overall media concern with a drug epidemic. From a longer historical perspective, however, this choice was not unique to the Crack Scare. The researchers generally have been more attentive to the "clouds" in their data than to the "silver linings." They apparently see their role as the canary in the mine, not the rooster announcing the dawn. In other instances, the researchers made choices in the mid-1980s that were more specific to the political context. For example, the press releases available to the media in 1986 paid little attention to smoking, acknowledging only briefly that adolescents were much more likely to use tobacco than any illegal drug. In contrast, at least since the mid-1990s, the researchers have issued separate and equally lengthy press releases on smoking, giving it at least equal billing with all other kinds of drug use.

In short, in addition to paying attention to the absence as well as the presence of numbers in the media, teachers and students of statistical literacy should understand the social construction of numbers in the media as involving not one decision, but a continuum of decisions. To return to the study that is the jumping off point for this paper: Orcutt and Turner (1993) do a good job examining one part of the social construction of numbers during the Crack Scare, but there is a bigger story to be told.

\section{Acknowledgments}

I did the research for this paper while on a Senior Sabbatical Fellowship from Amherst College and presented an earlier version of the paper at the 2010 meetings of the Eastern Sociological Society. I thank Len Vacher and four reviewers for their very helpful comments on the manuscript and their interest in my work.

\section{References}

Alonso, W. and P. Starr. 1987. The Politics of numbers. New York: Russell Sage Foundation.

Andreas, P. and K. M. Greenhill. 2010. Sex, drugs, and body counts: The politics of numbers in global crime and conflict. Ithaca, NY: Cornell University Press.

Barol, B. 1986. Cocaine babies: Hooked at birth. Newsweek, July 28, 56. 
Baum, D. 1996. Smoke and mirrors: The war on drugs and the politics of failure. Boston: Little, Brown.

Bertram, E. 1996. Drug war politics: The price of denial. Berkeley: University of California Press.

Best, J. 1993. Threatened children: Rhetoric and concern about child-victims. Chicago: University of Chicago Press. .2001a. Damned lies and statistics: Untangling numbers from the media, politicians, and activists. Berkeley: University of California Press. . 2001b. Promoting bad statistics. Society 38(3): 10-15. http://dx.doi.org/10.1007/BF02686213 .2004. More damned lies and statistics: How numbers confuse public issues. Berkeley: University of California Press. . 2008a. Birds-Dead and deadly: Why numeracy needs to address social construction. Numeracy 1(1): Article 6. http://dx.doi.org/10.5038/1936-4660.1.1.6 (accessed May 30, 2013) . 2008b. Social problems. New York: W.W. Norton \& Co. 2008c. Stat-spotting: A field guide to identifying dubious data. Berkeley: University of California Press.

Brinkley, J. 1986. U.S. Says cocaine-related deaths are rising. New York Times July 11, A1.

Deseran, T. A. and J. D. Orcutt. 2009. The deconstruction of a drug crisis: Media coverage of drug issues during the 1996 presidential campaign. Journal of Drug Issues 39(4): 871-891. http://dx.doi.org/10.1177/002204260903900405

Domash, S. F.1986. Use of the drug 'Crack' growing on L.I. New York Times June 8, LI5

Douglas, J. D. 1967. The social meaning of suicide. Princeton, NJ: Princeton University Press.

Ericson, R. V. 1998. How journalists visualize fact. The Annals of The American Academy of Political and, Social Science 560: 83. http://dx.doi.org/10.1177/0002716298560001007

Ferree, M. M., W. A. Gamson, and D. Rucht. 2002. Shaping abortion discourse: democracy and the public sphere in Germany and the United States. New York: Cambridge University Press. http://dx.doi.org/10.1017/CBO9780511613685

Gal, Iddo. 2002. Adults' statistical literacy: Meanings, components, and responsibilities. International Statistical Review 70(1): 1-25. http://dx.doi.org/10.2307/1403713

Gamson, W. A. 1992. Talking politics. New York: Cambridge University Press.

Gigerenzer, G., Z. Swijtink, T. Porter, L. Daston, J. Beatty, and L. Kruger.1989. The Empire of chance: How probability changed science and everyday life. New York: Cambridge University Press.

Goode, E. 1989. The American drug panic of the 1980s: Social construction or objective threat? Violence, Aggression, and Terrorism 3(4): 327-348.

Goode, E., and N. Ben-Yehuda. 2009. Moral panics: The social construction of deviance. Malden, MA: Wiley-Blackwell. http://dx.doi.org/10.1002/9781444307924

Gross, J. 1986. Rise in cocaine abuse poses threat to infants. New York Times. February 3 , B1. 
Hartman, D. M., and A. Golub. 1999. The social construction of the crack epidemic in the print media. Journal of Psychoactive Drugs 31(4): 423-433. http://dx.doi.org/10.1080/02791072.1999.10471772

Himmelstein, Jerome L. 2013. Hidden choices and missing numbers: Selecting drug numbers for media attention. Journal of Drug Issues 43(4): 437-449. http://dx.doi.org/10.1177/0022042613475615

Howlett, P., and M. S. Morgan, ed. 2011. How well do facts travel?: The dissemination of reliable knowledge. New York: Cambridge University Press.

Igo, S. E. 2007. The averaged American: Surveys, citizens, and the making of a mass public. Cambridge, MA: Harvard University Press.

Jensen, E. L., J. Gerber, and G. M. Babcock. 1991. New war on drugs: Grass roots movement or political construction? Journal of Drug Issues 21(3): 651-667.

Johnston, L. D. 1989. America's drug problem in the media: Is it real or is it Memorex. In Shoemaker 1989, 97-112.

Kerr, P. 1986a. Extra-potent cocaine: Use rising sharply among teen-agers. New York Times, March 20, 1. . 1986b. Drug treatment in City is strained by crack, a potent new cocaine: Potent form of cocaine straining drug programs. New York Times, May 16, A1. . 1986c. Crack addiction spreads among the middle class. New York Times, June 8, Section 1, Page 1. . 1986d. Babies of crack users fill hospital nurseries: Crack users' babies crowding hospital nurseries. New York Times, August 25, B1. . 1986e. Use of crack: The future: unclear how widely the drug will spread use of crack: The future is unclear. New York Times, September 1, 25. 1986f. Crack burdening a Justice system. New York Times, November 24, A1.

Keyfitz, N. 1987. The social and political context of population forecasting. In Alonso and Starr 1987, 235-258.

Massing, M. 1998. The fix. New York: Simon \& Schuster.

McKillop, P. 1986. An inferno of craving, dealing and despair. Newsweek, June 16, 18.

Melvin, T. 1986. Hearing called to explore use of "crack" by teen-agers." New York Times, April 27, WC1.

Monitoring the Future.2012. "Monitoring the future." http://monitoringthefuture.org/ (accessed July 11, 2012)

Morganthau, T. 1986a. Kids and Cocaine. Newsweek, March 17, 58. . 1986b. Crack and crime. Newsweek, June 16, 16.

Musto, D. F. 1999. The American Disease: origins of narcotic control. 3rd ed. New York: Oxford University Press.

Newsweek. 1986. The drug crisis: Crack and crime. Newsweek, June 30, 3.

Orcutt, J. D., and J. B. Turner. 1993. Shocking numbers and graphic accounts: Quantified images of drug problems in the print media. Social Problems 40(2):190206. http://dx.doi.org/10.2307/3096921

Power, M. 1997. The audit society: Rituals of verification. New York: Oxford University Press.

Prewitt, K. 1989. Public statistics and democratic politics. In Alonso and Starr, 261-274. 
Reese, S. D. and L. H. Danielian. 1989. "Intermedia influence and the drug issue: Converging on cocaine." In Shoemaker 1989, 29-46.

Reeves, J. L., and R. Campbell. 1994. Cracked coverage: Television news, the anticocaine crusade, and the Reagan legacy. Durham, N.C.: Duke University Press.

Reinarman, C., and H. G. Levine, ed. 1997. Crack in America: Demon drugs and social justice. Berkeley: University of California Press.

Sauder, M., and W. N. Espeland. 2009. The discipline of rankings: Tight coupling and organizational change. American Sociological Review 74(1): 63-82. http://dx.doi.org/10.1177/000312240907400104

Schield, M. 2011. Teaching the social construction of statistics. http://www.conkerstatistics.co.uk/iase/papers/IASE2011Paper\%206.4Schield.pdf (accessed July 6, 2012)

Schmidt, W. E. 1986. Police say use of crack is moving to small towns and rural areas. New York Times, September 10, 1.

Seligmann, J. 1986. Crack: The road back. Newsweek, June 30, 52.

Shoemaker, P. J., ed. 1989. Communication campaigns about drugs: Government, media, and the public. Hillsdale, NJ: Lawrence Erlbaum Associates.

Smith, R. M. 1986. The plague among us: The drug crisis. Newsweek, June 16, 15.

Strathern, M., ed. 2000. Audit cultures: anthropological studies in accountability, ethics, and the academy. New York: Routledge.

Thernstrom, A. 1989. Statistics and the politics of minority representation: The evolution of the Voting Rights Act since 1965. In Shoemaker 1989, 303-328.

Trebach, A. S. 1987. The Great Drug War: and radical proposals that could make America safe again. New York: Macmillan.

Urla, J. 1993. Cultural politics in an age of statistics: numbers, nations, and the making of Basque identity. American Ethnologist 20(4):818-843. http://dx.doi.org/10.1525/ae.1993.20.4.02a00080

Wagner, D. 1997. The New Temperance: the American obsession with sin and vice. Boulder, Colo.: Westview Press. 